\title{
Excess of bottom-released methane in an Arctic shelf sea polynya in winter
}

\author{
Ellen Damm ${ }^{\mathrm{a}, *}$, Ursula Schauer ${ }^{\mathrm{a}}$, Bert Rudels ${ }^{\mathrm{b}}$, Christian Haas ${ }^{\mathrm{a}}$ \\ ${ }^{a}$ Alfred Wegener Institute for Polar and Marine Research, P.O. Box 120161 D-27515 Bremerhaven, Germany \\ ${ }^{\mathrm{b}}$ Finnish Institute of Marine Research, P.O. Box 2, Erik Palmenin aukio 1, FIN-00561 Helsinki, Finland
}

Received 24 July 2006; received in revised form 16 January 2007; accepted 5 February 2007

Available online 3 March 2007

\begin{abstract}
Latent heat polynyas are regions generating strong ice formation, convection and extensive water mass formation. Here we report on the effects of these processes on resuspension of sediments and subsequent methane release from the seafloor and on the resulting excess methane concentration in surface water on a polar shelf during winter. The study is based on measurements of concentration and $\delta^{13} \mathrm{C}$ values of methane, water temperature, salinity, light transmission and sea ice data collected in March 2003 in Storfjorden, southern Svalbard. In winter, strong and persistent northeasterly winds create polynyas in eastern Storfjorden and cause ice formation. The resulting brine-enriched water cascades from the Storfjordbanken into the central depression thereby enhancing the turbulence near the seafloor. A distinct benthic nepheloid layer was observed reflecting the resuspension of sediments by the cascading dense bottom water. High concentrations of ${ }^{13} \mathrm{C}$-depleted methane suggest submarine discharge of methane with the resuspended sediments. As the source of the submarine methane, we propose recent bacterial methanogenesis near the sediment surface because of extremely high accumulation rates of organic carbon in Storfjorden. Convective mixing transports newly released methane from the bottom to the sea surface. This eventually results in an excess concentration in surface water with respect to the atmospheric equilibrium, and a sea-air flux of methane during periods of open water. When a new ice cover is formed, methane becomes trapped in the water column and subsequently oxidized. Thus, the residual methane is strongly enriched in ${ }^{13} \mathrm{C}$ in relation to the $\delta^{13} \mathrm{C}_{\mathrm{CH}_{4}}$ signature of atmospheric methane. Our results show that latent heat polynyas may induce a direct pathway for biogases like methane from sediments to the atmosphere through coupling of biogeochemical and oceanographic processes. Extrapolating these processes to all Arctic ocean polynyas, we estimate a transfer of $\mathrm{CH}_{4}$ between 0.005 and $0.02 \mathrm{Tg} \mathrm{yr}^{-1}$. This is not a large contribution but the fluxes from the polynyas are 20-200 times larger than the ocean average and the methane evasion process in polynyas is certainly one that can be altered under climate change.
\end{abstract}

(C) 2007 Elsevier Ltd. All rights reserved.

Keywords: Methane; Stable carbon isotopes; Oceanic convection; Polynyas; Arctic; Spitsbergen; Storfjorden

\section{Introduction}

*Corresponding author. Tel.: + 4948311423 ; fax: +4948311425 .

E-mail address: edamm@awi-bremerhaven.de (E. Damm).
Oceanic circulation has a profound effect on biogeochemical cycles and water mass formation on the shallow Arctic shelf seas, especially in polynyas, 
and may play a prominent role in this respect. In winter, vigorous freezing and brine-induced haline convection occur in areas where open water is created recurrently due to divergent sea ice movement. These polynyas will, because of their complex dynamics, lead to enhanced vertical transports. If the water is shallow and the stratification weak, the convection will reach the bottom and thus establish a communication between ocean floor and atmosphere.

Here we report on enhanced vertical transport of submarine methane to the atmosphere because of complex dynamics involving freezing, brine rejection and haline convection in a prominent polynya occurring each winter in Storfjorden in the Svalbard Archipelago in the western Barents Sea (Fig. 1). Typically, the polynya is created by strong northeasterly winds over the shallow (depth $<50 \mathrm{~m}$ ) Storfjordbanken at the eastern rim of Storfjorden. Dense, brine-enriched water is formed, sinks to the bottom and subsequently drains from Storfjordbanken to the central depression (Haarpaintner et al., 2001a). Anderson et al. (2004) found a transfer of $\mathrm{CO}_{2}$ from the atmosphere to the bottom waters of the central Storfjorden caused by sinking of $\mathrm{CO}_{2-}$ enriched surface waters.

The coupled processes described here generate pathways along which methane may escape directly

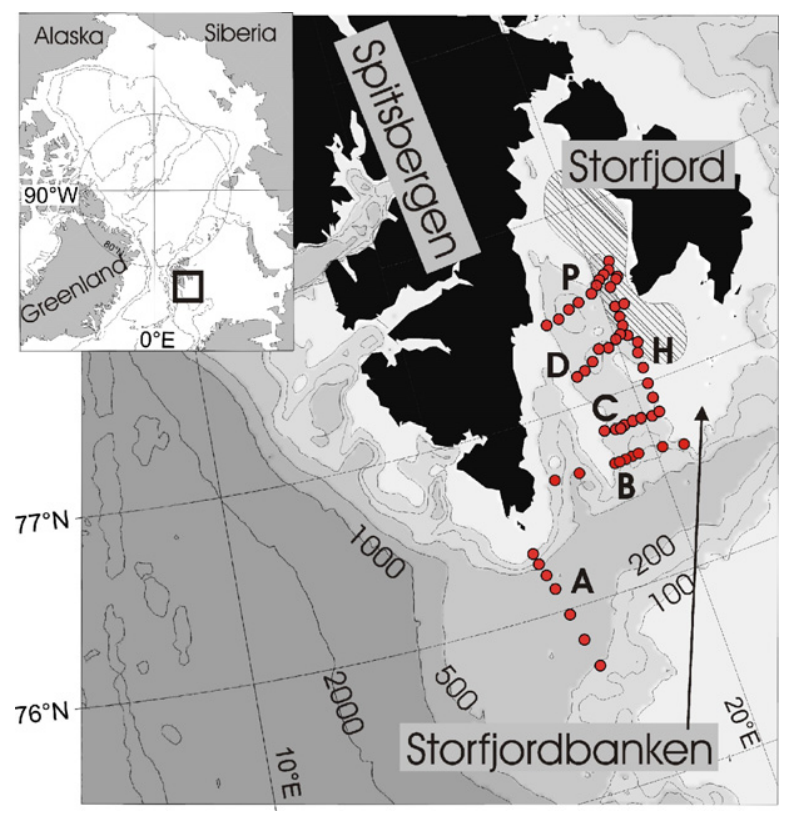

Fig. 1. Station map in Storfjorden. The polynya area (schematically redrawn after Haarpaintner et al., 2001b) is hatched, A-P are the transects. Numbers at thin lines give bottom depth in $\mathrm{m}$. from sediments to the atmosphere, reducing its turnover time in the seasonally ice-covered Arctic shelf seas.

\section{Data and methods}

During the ARK XIX/1 cruise of RV Polarstern in March 2003 (Schauer and Kattner, 2004), five hydrographic transects were obtained within and south of Storfjorden (Fig. 1). Salinity, temperature and light transmission were measured with a Seabird SBE $911+$ CTD and C-Star Wetlabs transmissometer. Water samples from up to eight different depths were collected during the upcast at each CTD station with 101 Niskin bottles mounted on a rosette sampler. Water samples for methane measurements were taken immediately from the Niskin bottles and, within a few hours, the dissolved gas was extracted from the water by vacuum-ultrasonic treatment. Methane concentrations were measured with a gas chromatograph Chrompack 9003 (GC) with flame ionization detector (FID) (Lammers et al., 1995). For GC separation, we used a packed column (Porapac Q $80 / 100$ mesh). The GC oven was operated isothermally $\left(60^{\circ} \mathrm{C}\right)$ and the heated zone of the FID was held at a temperature of $250{ }^{\circ} \mathrm{C}$. Two sets of standard gas mixtures were used for calibration. The standard deviation of duplicate analyses was $5-10 \%$. This high overall error is almost exclusively due to the gas extraction procedure and not to GC precision, which had an error of only $1 \%$. After GC analyses, the remainder of the gas was transferred into evacuated glass containers for analysis of the carbon isotopic signature on shore. The $\delta^{13} \mathrm{C}_{\mathrm{CH}_{4}}$ values were determined by continuous-flow isotope ratio mass spectrometry (CF-IRMS) (Popp et al., 1995). Depending on the concentration of methane, the reproducibility derived from duplicates was $0.5-1 \%$. Isotopic ratios are reported relative to the Pee Dee Belemnit (PDB) standard using conventional delta notation (Craig, 1957).

\section{Results and discussion}

\subsection{Sediment resuspension and discharge of submarine methane}

In Storfjorden, strong salinity stratification close to the bottom indicated that new brine-enriched water had been created in the previous months. In the upper part of the water column, the salinity 
increased from west to east with the highest values found over the shallow Storfjordbanken in the eastern part of the fjord, the location of the polynya. Here, the water column was almost homogeneous, indicating convection to the sea floor. The stratification and the high-bottom salinities found further to the west thus imply that dense, brine-enriched water had cascaded from Storfjordbanken towards the central depression. The bottom-water salinity was about 1 psu less than the year before (Skogseth et al., 2005) indicating that the central depression was completely flushed by fresher water in summer or autumn 2002 before new brine release started in winter 2003. Our observations showed that the densest bottom water had a very reduced light transmission, suggesting that the turbulence at the bottom was above the resuspension threshold (Figs. 2 and 3). This is in agreement with Sternberg et al. (2001), who observed that the flow of brine-enriched water along the bottom induces turbulence near the seafloor strong enough to resuspend sediments. In contrast to the eastern area with the polynya, the western part of Storfjorden was covered by ice and the about $50 \mathrm{~m}$-thick low-salinity surface-mixed layer observed there suggests that no dense water had been created. Consequently, no brine-enriched water flowed along the seafloor from the western area and no sediment was resuspended, which was supported by high light transmission (Fig. 3). The turbidity at the bottom in the central depression thus resulted from particles transported with the plume of brine-enriched water from the polynya region in the eastern part (Figs. 2 and 3).

The concentration of methane in the entire Storfjorden exceeded the marine background concentration, which is in equilibrium with the atmospheric value at about 3.5-4 nM (Wiesenburg and Guinasso, 1979). However, the methane distribution was inhomogeneous with concentrations increasing from west to east and from the sea surface to the bottom. The concentration was highest $(48.3 \mathrm{nM})$ at the sea floor in the northeastern corner, which is the area of the recurrent polynya (Figs. 1 and 4, P-transect). The carbon isotopic composition of methane was also inhomogeneous and the lightest $\delta^{13} \mathrm{C}$ values $(-52.6 \%$ \% $\mathrm{PDB})$ were detected in the polynya area (Fig. 5).

Microcosm studies have shown that resuspension events may discharge reduced compounds into the water column (Bussmann, 2004). We propose that the enhanced turbulence at the bottom in the polynya region causes sediment resuspension and a release of submarine methane. Because of extremely high accumulation rates of organic carbon (between 5 and $17 \mathrm{~g} \mathrm{~m}^{-2} \mathrm{yr}^{-1}$ ), Storfjorden is an ideal environment for the formation of bacterial methane near the sediment surface (Winkelmann and Knies, 2005). The average $\delta^{13} \mathrm{C}_{\mathrm{CH}_{4}}$ value $(-51 \%$ PDB $)$ of the bottom-released methane is consistent with this origin (Whiticar, 1999).

For plume formation and turbulent mixing models, typically, a dilution factor of $10^{4}$ is assumed (Lupton et al., 1985). Hence, to create a plume with the methane concentration detected in the Storfjorden bottom water (about $50 \mathrm{nM}$ ), a potential initial concentration of roughly $0.5 \mathrm{mM}$ in the surface sediments would be sufficient. This is a methane concentration which is tolerated even in sulfate-rich marine sediment (Kiene, 1991), where methanogenesis is usually severely restricted by other bacterial assemblages, e.g. sulfate-reducing bacteria, which more effectively utilize labile carbon compounds (Whiticar, 1999). Thus, we suggest that the decomposition of the recent primary production of organic matter supplies the methane in Storfjorden. In comparison, release of fossil methane from seepages would cause a much higher concentration like that detected in the ice-covered Sea of Okhotsk where methane is accumulated in concentrations $>300 \mathrm{nM}$ under the ice (Lammers et al., 1995).

\subsection{Vertical transport to the sea surface and sea-air flux}

During ice formation in the polynya, mixing caused by the wind and/or by destabilization of the water column rapidly transports the bottom-released methane to the sea surface. On its passage from the bottom to the surface, a weak decrease in methane concentration occurs, reflecting a slight dilution of bottom-released methane in water with marine background methane values (Figs. 4 and 5, $\mathrm{H}$-transect). The carbon isotopic signatures of the two methane reservoirs differ only little $(-51 \%$ for the bottom-released methane and $-47 \%$ for the background methane) so that mixing will not change the $\delta^{13} \mathrm{C}_{\mathrm{CH}_{4}}$ value substantially. Obviously, the transport by convective mixing happens too fast to allow a consumption of methane by oxidation so that an excess concentration with respect to the atmospheric equilibrium concentration is induced in the surface water of the polynya region. During periods of open water, i.e., during strong easterly 
A

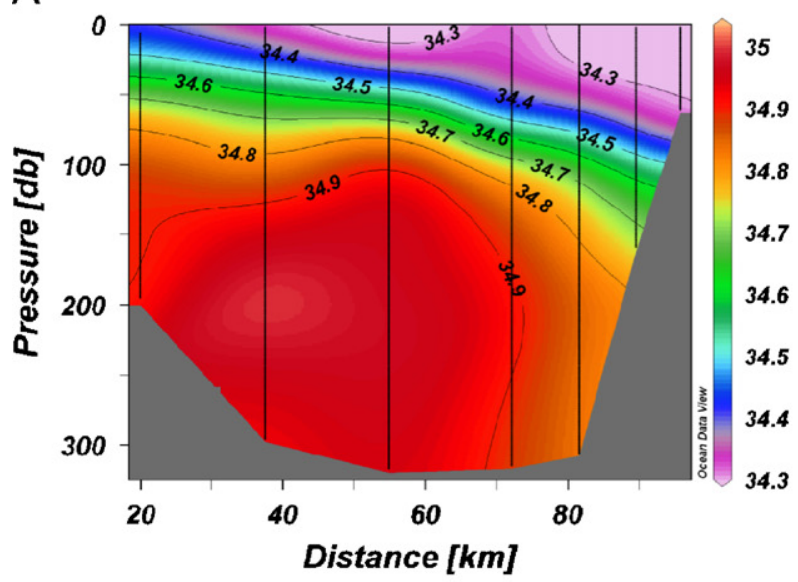

C

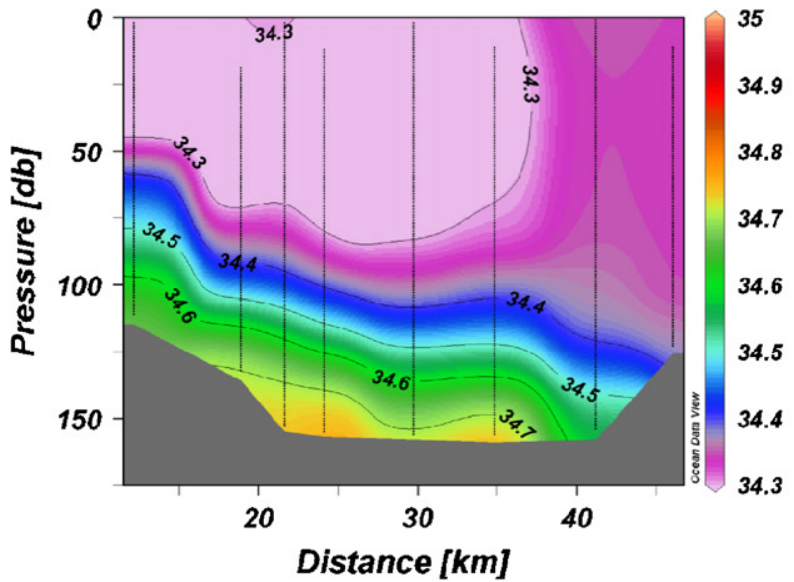

P

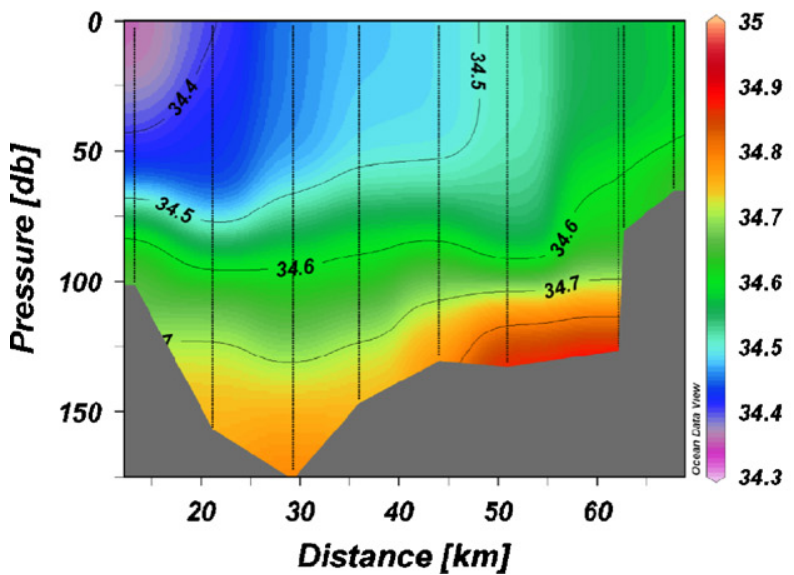

B

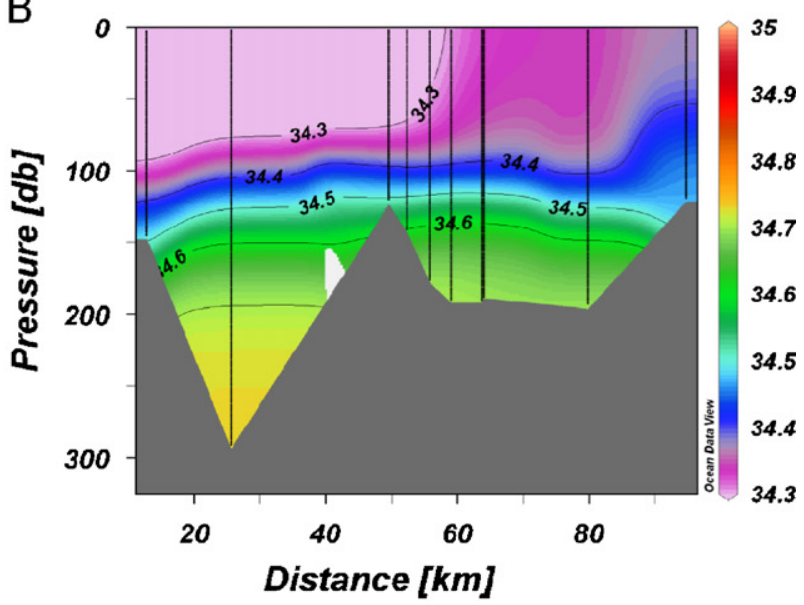

D

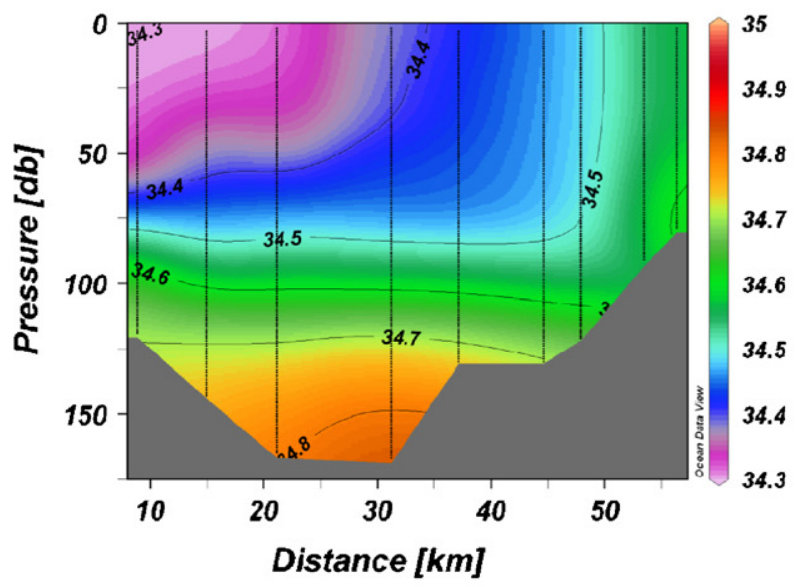

$\mathrm{H}$

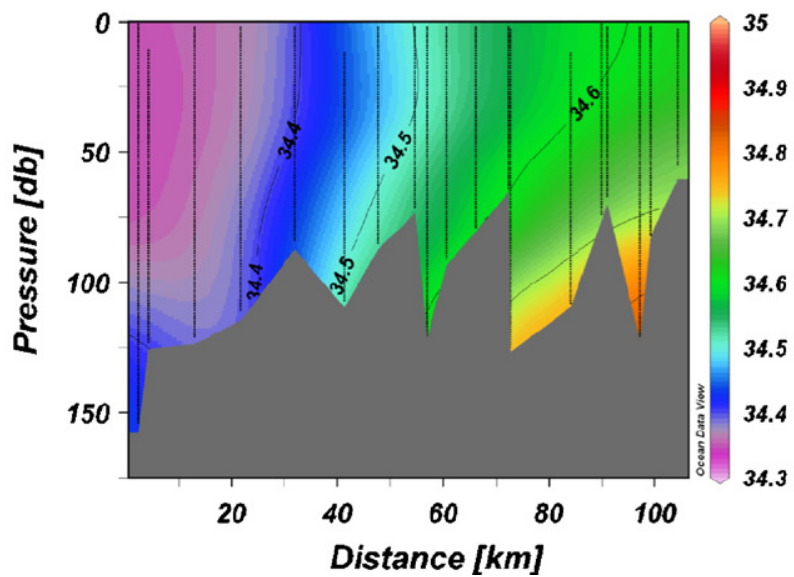

Fig. 2. Salinity in Storfjorden. For the position of transects, see Fig. 1. The transects B, C, D and P run from west to east, the transects A and $\mathrm{H}$ run from south to north. The salinity increases from west to east due to the creation of brine-enriched water. The convection to the sea floor induces a homogeneous water column on the eastern fjord edge, i.e., in the polynya region. 
A

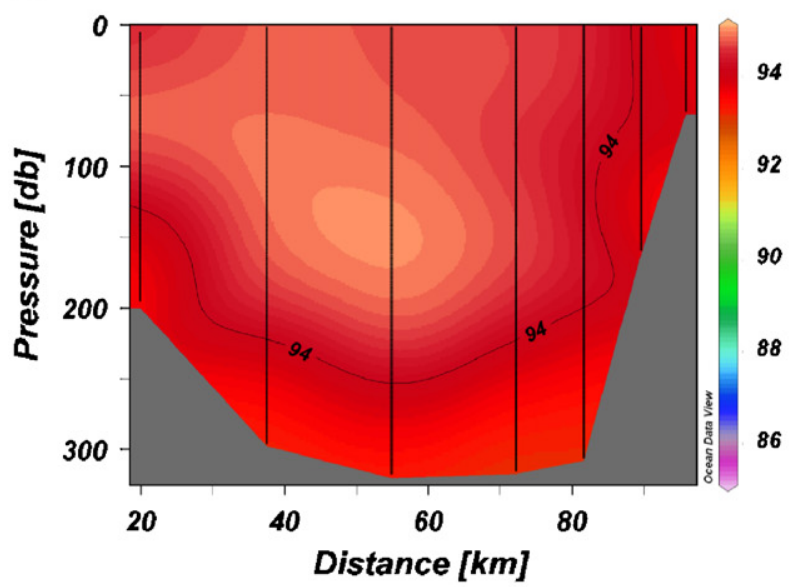

C

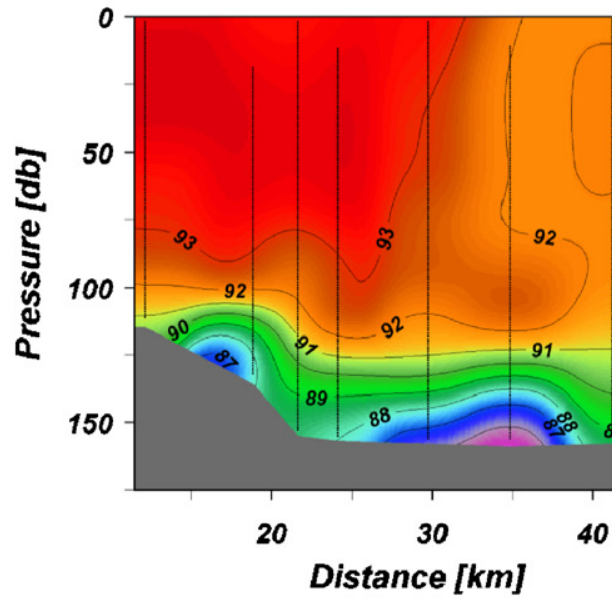

$P$

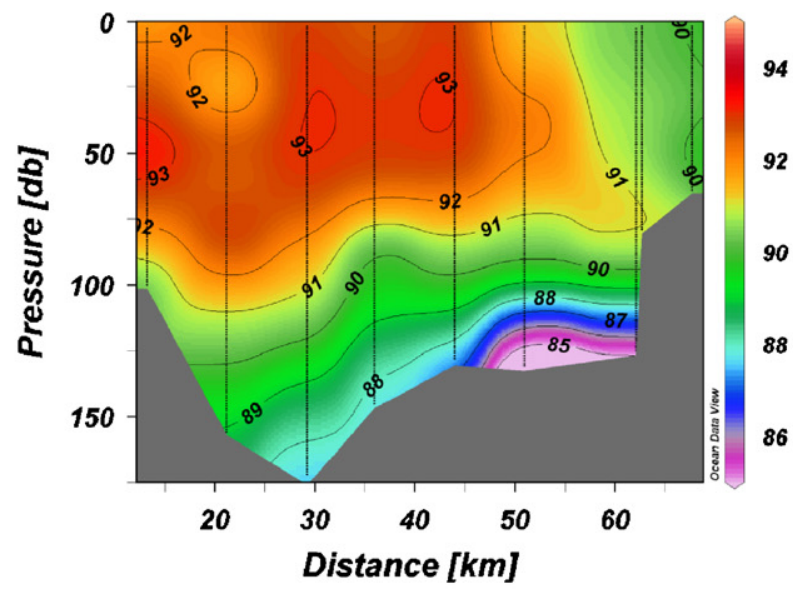

B

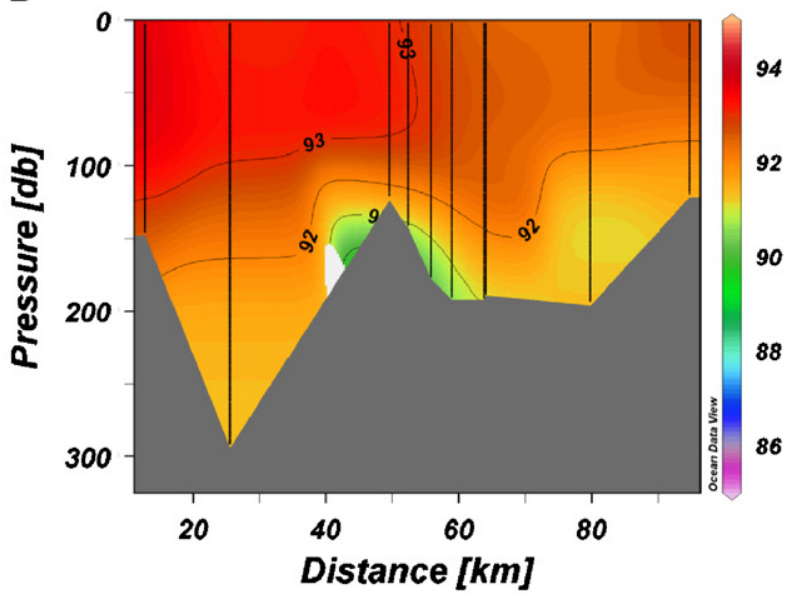

D

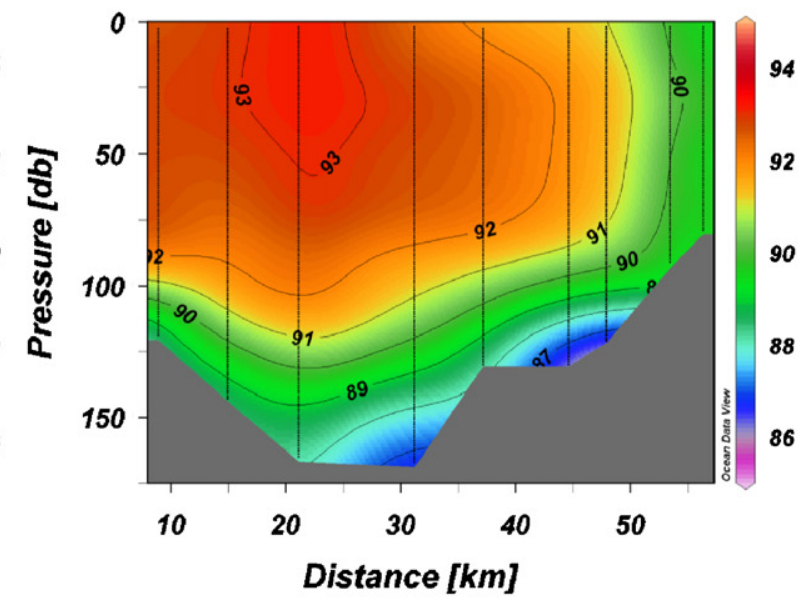

$\mathrm{H}$

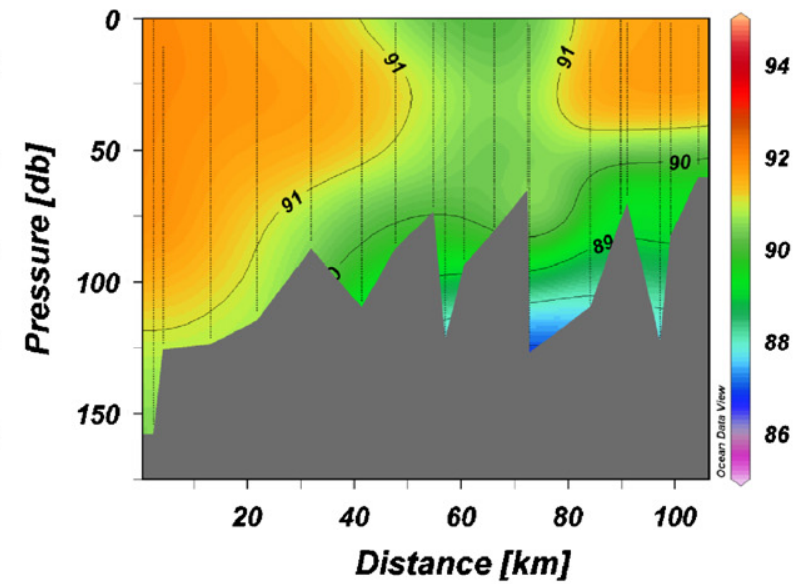

Fig. 3. The light transmission (in \%) in Storfjorden. For the position of transects, see Fig. 1. The transects B, C, D and P run from west to east, the transects $\mathrm{A}$ and $\mathrm{H}$ run from south to north. On the eastern edge, the light transmission is reduced because of resupended sediments. The resuspension events reflect the turbulence at the bottom generated by brine-enriched water cascading from the eastern edge into central depression. 
A
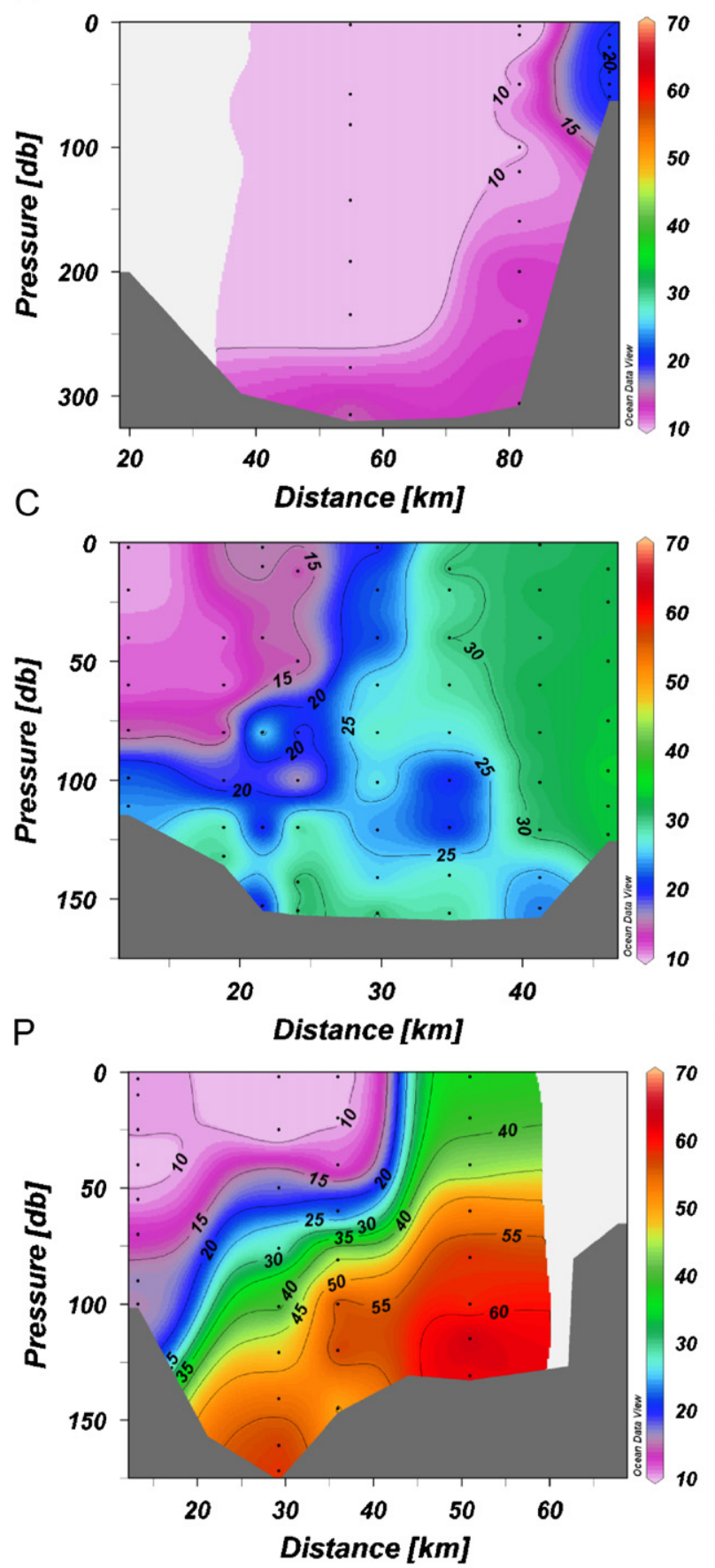

B
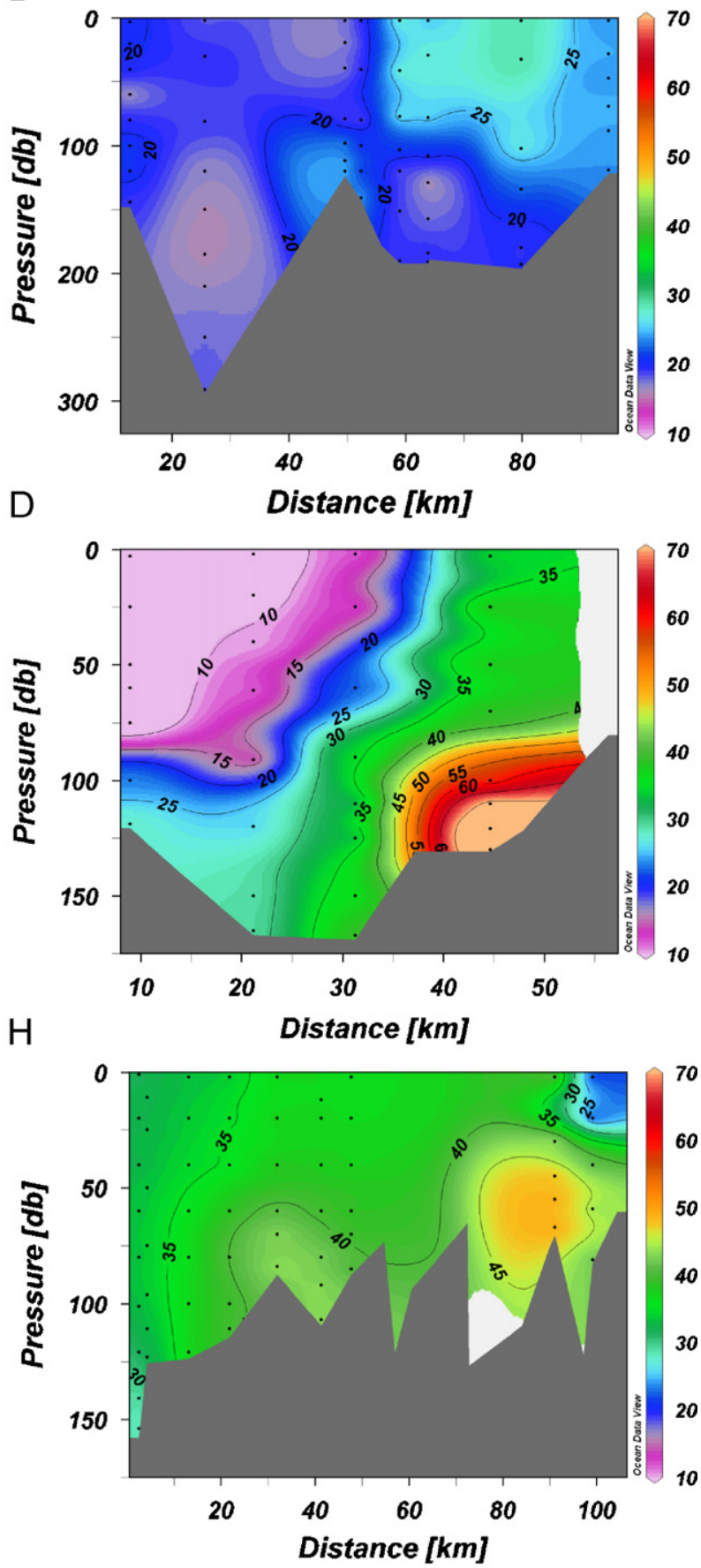

Fig. 4. Methane concentration (in $\mathrm{nM}$ ) in Storfjorden. For the position of transects, see Fig. 1. The transects B, C, D and P run from west to east, the transects A and H run from south to north. Data gaps are marked by white regions. Highest methane concentrations exist on the seafloor of the northeast edge, suggesting a submarine methane discharge in the polynya region.

winds, the excess methane will be released to the atmosphere. The flux, $F$ between the ocean surface and the atmosphere is described as a function of the difference between methane concentrations in the surface water and in the air, $\Delta C$, and the gas exchange coefficient, $k$, as $F=k \Delta C$. The coefficient $k=0.31 v^{2}(S c / 660)-0.5$ (Wanninkhof, 1992) depends on the wind speed, $v$, and the Schmidt 
A

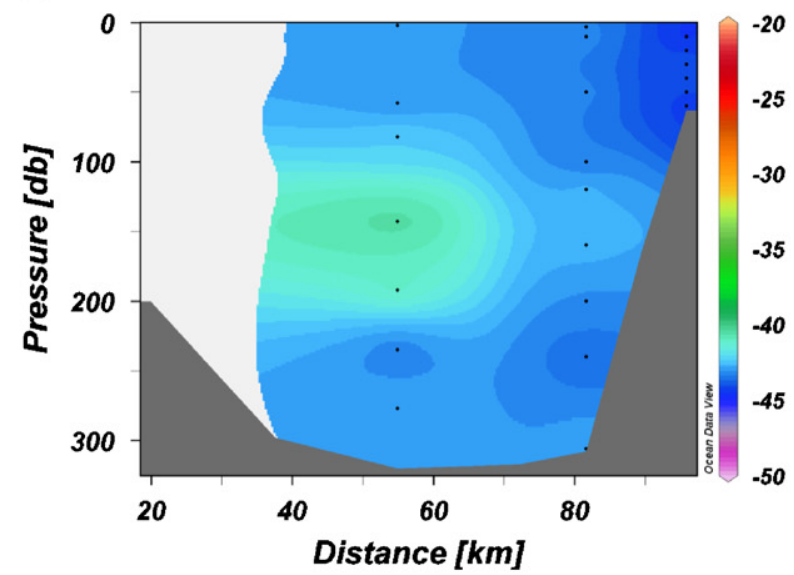

C

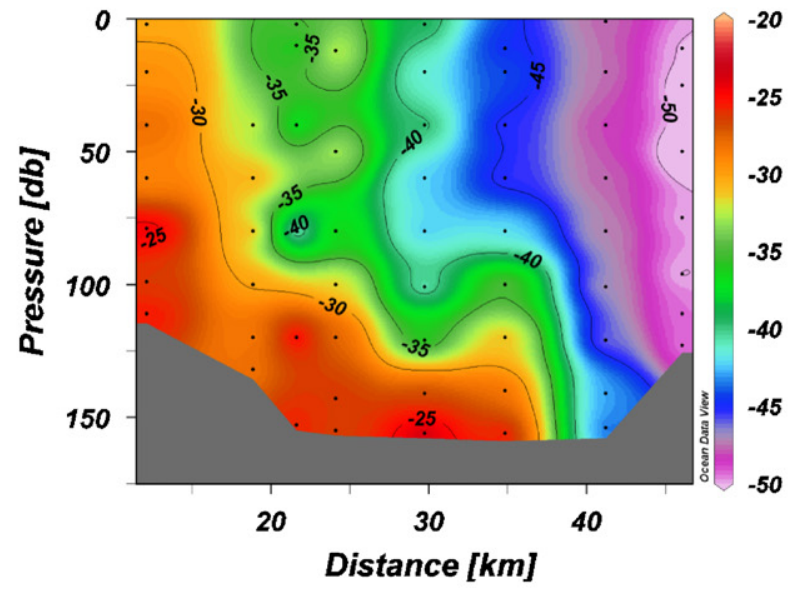

$\mathrm{P}$

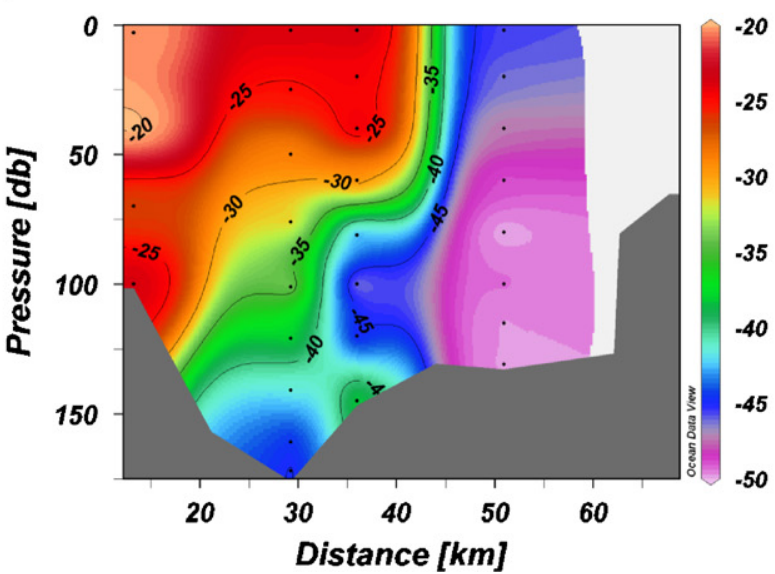

B

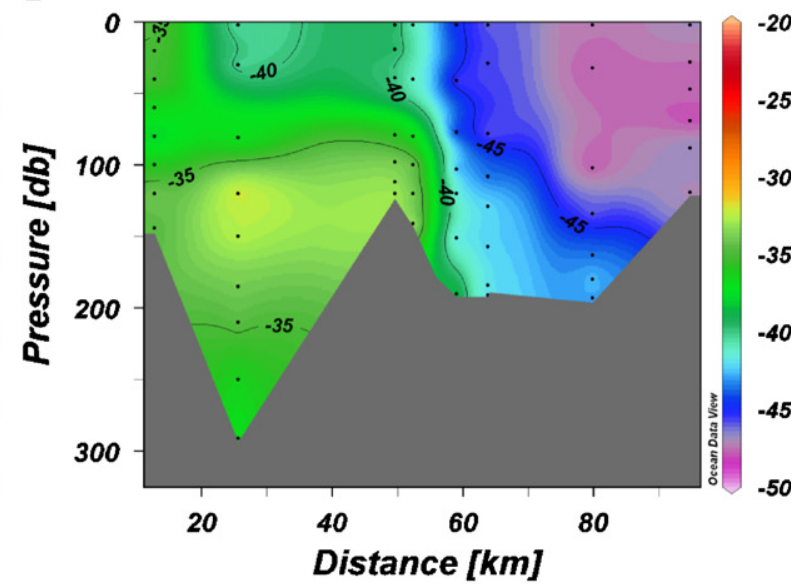

D

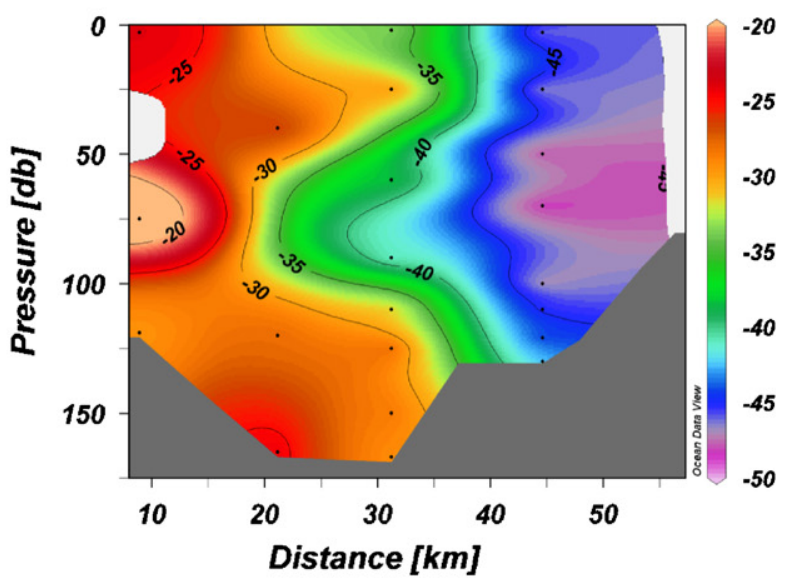

$\mathrm{H}$

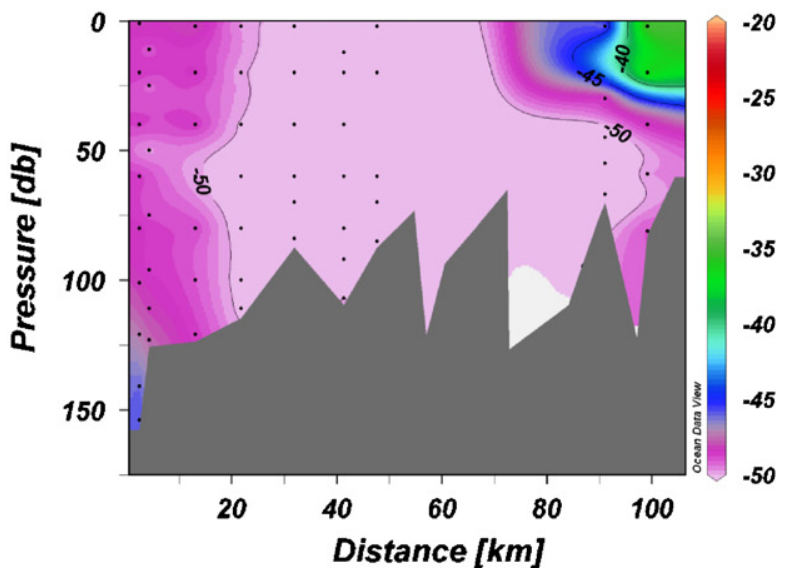

Fig. 5. $\delta^{13} \mathrm{C}_{\mathrm{CH}_{4}}$ values (in \%o PDB) in Storfjorden. For the position of transects see Fig. 1. The transects B, C, D and P run from west to east, the transects $\mathrm{A}$ and $\mathrm{H}$ run from south to north. Data gaps are marked by white regions. The depletion in ${ }^{13} \mathrm{C}$ refers to the bacterial formation of the submarine-released methane. During residence time in the ice-covered seawater, methane is oxidized and thus the residual methane is becoming enriched in ${ }^{13} \mathrm{C}$. 
number, $S c$, which is 2667 for methane dissolved in seawater at a temperature of $-1.8^{\circ} \mathrm{C}$ according to Wanninkhof (1992). From the observed concentration difference of $\Delta C=26 \mathrm{nM}$, we conclude that the methane flux can reach values between 26 and $104 \mu \mathrm{mol} / \mathrm{m}^{2} \mathrm{~d}$ for wind speeds of 5 and $10 \mathrm{~m} / \mathrm{s}$, respectively. This is much larger than the average sea-air flux of methane for the world ocean, which is estimated to be between 2.4 and $24 \mu \mathrm{mol} / \mathrm{m}^{2} \mathrm{~d}$ (Prather et al., 1995). Because of the depletion in ${ }^{13} \mathrm{C}$ of the submarine methane in relation to the atmospheric $\delta^{13} \mathrm{C}_{\mathrm{CH}_{4}}$ signature, this process adds isotopically light methane to the atmospheric methane reservoir.

\subsection{Methane oxidation in ice-covered seawater}

Accumulation of ice in the polynya area interrupts the sea-air flux of methane. Horizontal gradients in salinity and methane concentration show that saline- and methane-rich water from the polynya area is also mixed along isopycnals into the interior ice-covered Storfjorden. However, in contrast to the conservative behavior of salinity, methane trapped below the ice is partially consumed by aerobic oxidation. The bacterial oxidation is the only sink for the methane in water. There is no further input and the isotopic composition is not affected by mixing. This means that a Rayleigh distillation model, as discussed by Coleman et al.
(1981), can be used to estimate the oxidation. In surface water, the best fit to the data is found with a kinetic isotopic fractionation factor of 1.017 , with initial concentrations of 30 and $50 \mathrm{nM}$, and initial $\delta^{13} \mathrm{C}_{\mathrm{CH}_{4}}$ values of -50 and $-52 \%$, respectively (Fig. 6). The fractionation factor lies well within the range associated with oxidation processes (Whiticar and Faber, 1986; Whiticar, 1999). The differences in the initial concentrations reflect the different degrees of dilution with ambient waters, which occurs during the transport of bottom-released methane through the water column. Oxidation starting from the lower initial concentration indicates that methane-rich water was diluted before the oxidation started. The increasing oxidation stage documented by the increasing enrichment in ${ }^{13} \mathrm{C}$ reflects the aging of the residual methane due to the longer residence time of methane in water. Eventually, two-thirds of the initial methane is consumed by oxidation during transport from east to west (from the release area to the central depression (Fig. 5). The residual methane concentration of roughly $10 \mathrm{nM}$ in western Storfjorden coincides with threshold values also detected in shelf water of Westspitsbergen (Damm et al., 2005).

Due to oxidation, methane in the surface water becomes extremely enriched in ${ }^{13} \mathrm{C}$ (Fig. 5 and 6). In spring after ice melt, the residual, isotopically heavy methane may escape to the atmosphere. The frequency of polynya events and the duration of

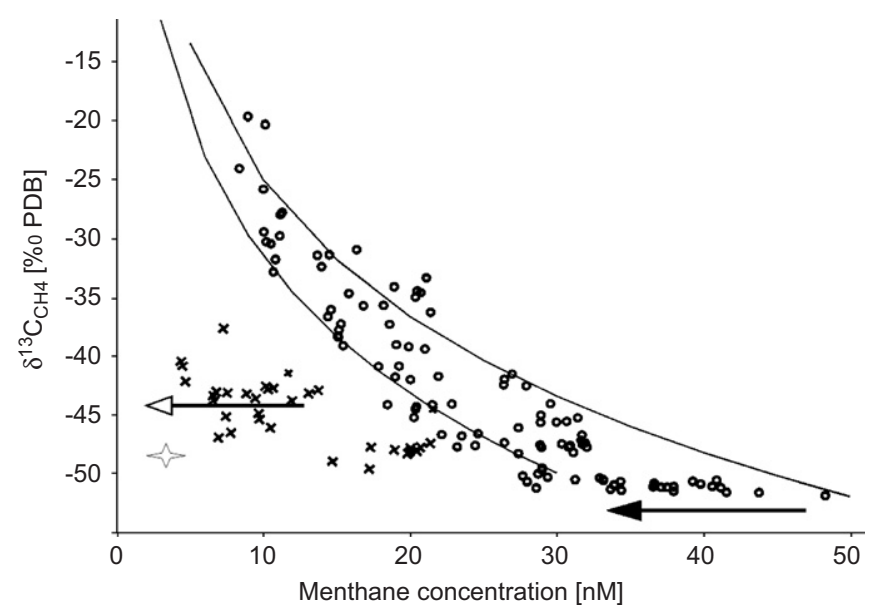

Fig. 6. $\delta^{13} \mathrm{C}_{\mathrm{CH}_{4}}$ values vs. methane concentration. Circles correspond to data in seawater with salinities $\leqslant 34.4$ in Storfjorden. Crosses show data from the transect A outside Storfjorden. Oxidation curves are calculated by a Rayleigh distillation with an isotopic fractionation factor of 1.017 and initial values of methane concentration and $\delta^{13} \mathrm{C}_{\mathrm{CH}_{4}}$ of $50 \mathrm{nM}$ and $-52 \%$ as well as $30 \mathrm{nM}$ and $-50 \%$, respectively. Filled arrow shows dilution of methane before oxidation occurs. Open arrow shows a dilution of the aged methane from Storfjorden in ambient seawater outside Storfjorden. The asterisk indicates the methane concentration and the $\delta^{13} \mathrm{C}_{\mathrm{CH}_{4}}$ value in equilibrium with the atmosphere (see text). 
ice coverage thus determine the sea-air flux as well as the final $\delta^{13} \mathrm{C}_{\mathrm{CH}_{4}}$ signature of submarine methane added to the atmospheric methane reservoir in spring.

The data from outside Storfjorden (transect A) deviate from those inside Storfjorden, with decreasing concentration at higher $\delta^{13} \mathrm{C}_{\mathrm{CH}_{4}}$ values. Such a pattern results if oxidation in methane-rich seawater occurs before this water is diluted with ambient, methane-free seawater. This is reflected at transect A, where out-flowing Storfjorden water with an aged methane inventory is traced.

\section{Summary and conclusions}

We observed excess (with respect to the atmosphere) methane concentration in winter over the entire water column in the recurrent polynya area of eastern Storfjorden. We propose that this methane is released from the seafloor during resuspension of sediments caused by enhanced turbulence during convective mixing in the polynya. The range of the methane concentration close to the seafloor is $<100 \mathrm{nM}$. As the source, we suggest bacterial production near the sediment surface in the shallow Storfjorden as a result of the high accumulation rates of organic matter. Since methane is transported rapidly to the sea surface by convective mixing, during periods of open water with strong northeasterly winds, a direct transfer of bottomreleased methane to the atmosphere occurs.

The Arctic marginal seas belong to the most productive environments on earth as regards organic matter, and high accumulation rates of organic carbon are common on the shallow shelves (Wassmann, 2002; Stein and McDonald, 2003). Thus the coupling of biogeochemical and oceanographic processes described above for the Storfjorden polynya is expected to occur also in other polynya areas in the Arctic ocean. Winsor and Björk (2000) investigated the activity of 28 polynya areas in the Arctic ocean over 39 years and estimated the total area-days in a year at about $3 \times 10^{6} \mathrm{~km}^{2} / \mathrm{d}$. Assuming the processes observed in Storfjorden to be applicable in these polynyas and that the amount of degraded organic matter is similar in these polynya areas to those in Storfjorden, an average flux of $26-104 \mu \mathrm{mol} / \mathrm{m}^{2} \mathrm{~d}$ gives a transfer of $0.005-0.02 \mathrm{Tg} \mathrm{CH}_{4}$ during the winter season. Using an the estimated flux from the ocean to the atmosphere of $2.4-24 \mu \mathrm{mol} / \mathrm{m}^{2} \mathrm{~d}$, (Prather et al., 1995) gives a flux of $5-50 \mathrm{Tg} \mathrm{CH}_{4} \mathrm{yr}^{-1}$ for the world ocean area. This suggests that the polynya areas might provide $0.04-0.4 \%$ of the total transfer of methane from the ocean to the atmosphere. This is not a large contribution, but the ratio of areadays for the polynyas to the area-days for the entire ocean is $0.002 \%$, which implies that the fluxes from the polynyas are 20-200 times larger than the ocean average. Furthermore, less intense convection might reach the bottom when the polynyas are ice-covered and convection to the bottom may also occur at more permanently ice-covered shelf areas. This might lead to a release in methane that becomes capped at the sea surface by the ice cover. Most of this would, as we have shown above, be oxidized within the water column. However, some excess methane enriched in ${ }^{13} \mathrm{C}$ beneath the ice might still be present, and then, as the ice cover breaks up in spring, escape to the atmosphere. Since this convection and release could occur over a much larger part of the shelves than just in the polynyas, it could provide a short, seasonal source of heavy methane of similar strength as the combined polynya sources of light, i.e., ${ }^{13} \mathrm{C}$-depleted methane during winter. Finally, the methane evasion process described here is certainly one that can be altered with changing climate.

\section{Acknowledgments}

We are grateful to the scientific party and crew of RV Polarstern for their support on sea. We thank Robin Keir and two anonymous reviewers for thorough reviews and helpful advice.

\section{References}

Anderson, L.G., Falck, E., Jones, P., Jutterström, S., Swift, J.H., 2004. Enhanced uptake of atmospheric $\mathrm{CO}_{2}$ during freezing of seawater: a field study in Storfjorden, Svalbard. Journal of Geophysical Research 109, C06004.

Bussmann, I., 2004. Methane release through resuspension of littoral sediment. Biogeochemistry 74 (3), 283-302.

Coleman, D.D., Risatti, J.B., Schoell, M., 1981. Fractionation of carbon and hydrogen isotopes by methane-oxidizing bacteria. Geochimica et Cosmochimica Acta 45, 1033-1037.

Craig, H., 1957. Isotopic standards for carbon and oxygen and correction factors for mass-spectrometric analysis of carbon dioxide. Geochimica et Cosmochimica Acta 12, 133-149.

Damm, E., Mackensen, A., Budeus, G., Faber, E., Hanfland, C., 2005. Pathways of methane in seawater: plume spreading in an Arctic shelf environment (SW Spitsbergen). Continental Shelf Research 25 (12-13), 1433-1452.

Haarpaintner, J., O'Dwyer, J., Gascard, J.C., Haugan, P.M., Schauer, U., Østerhus, S., 2001a. Seasonal transformation of 
water masses, circulation and brine formation observed in Storfjorden, Svalbard. Annals of Glaciology 33, 437-443.

Haarpaintner, J., Gascard, J.C., Haugan, P.M., 2001b. Ice production and brine formation in Storfjorden, Svalbard. Journal of Geophysical Research 106, 14001-14013.

Kiene, P.R., 1991. Production and consumption of methane in aquatic systems. In: Rogers, J.E., Whitman, W.B. (Eds.), Microbial Production and Consumption of Greenhouse Gases: Methane, Nitrogen, Oxides, and Halomethanes. American Society for Microbiology, Washington, DC, pp. 111-146.

Lammers, S., Suess, E., Mansurov, M.N., Anikiev, V.V., 1995. Variations of atmospheric methane supply from the sea of Okhotsk induced by the seasonal ice cover. Global Biogeochemical Cycle 9, 351-358.

Lupton, J.E., Delaney, J.R., Johnson, H.P., Tivey, M.K., 1985. Entrainment and vertical transport of deep-ocean water by buoyant hydrothermal plumes. Nature 316, 621-623.

Popp, B.N., Sansone, F.J., Rust, T.M., Meritt, D.A., 1995. Determination of concentration and carbon isotopic composition of dissolved methane in sediments and nearshore waters. Analytical Chemistry 67, 405-411.

Prather, M., Derwent, R., Ehhalt, D., Fraser, P., Sanhueza, E., Zhou, X., 1995. Other trace gases and atmospheric chemistry. In: Houghton, J.T., et al. (Eds.), Climate Change 1994: Relative Forcing of Climate Change and an Evaluation of the IPCC IS92 Emission Scenario. Cambridge University Press, Cambridge, pp. 73-126.

Schauer, U., Kattner, G. (Eds.), 2004. The expedition ARKTIS XIX/1a, b and XIX/2 of the RV "Polarstern" in 2003. Reports on Polar and Marine Research, 481.
Skogseth, R., Haugan, P.M., Jakobsson, M., 2005. Watermass transformations in Storfjorden. Continental Shelf Research 25 (5-6), 667-695.

Stein, R., McDonald, R.W. (Eds.), 2003. The organic carbon cycle in the Arctic Ocean, 363 pp.

Sternberg, R.W., Aagaard, K., Cacchione, D., Wheatcroft, R.A., Beach, R.A., Roach, A.T., Marsden, M.A.H., 2001. Longterm near-bed observations of velocity and hydrographic properties in the northwest Barents Sea with implications for sediment transport. Continental Shelf Research 21, 509-529.

Wanninkhof, R., 1992. Relationship between wind speed and gas exchange over the ocean. Journal of Geophysical Research 97, 7373-7382.

Wassmann, P., 2002. Seasonal C-cycling variability in the open and ice-covered waters of the Barents Sea: an introduction. Journal of Marine Systems 38, 1-7.

Whiticar, M., 1999. Carbon and hydrogen isotope systematics of bacterial formation and oxidation of methane. Chemical Geology 161, 291-314.

Whiticar, M.J., Faber, E., 1986. Methane oxidation in sediment and water column environments-isotope evidence. Organic Geochemistry 10, 759-768.

Wiesenburg, D.A., Guinasso, N.L., 1979. Equilibrium solubilities of methane, carbon monoxide and hydrogen in water and seawater. Journal of Chemcal and Engineering Data 24 (1), 356-360.

Winkelmann, D., Knies, J., 2005. Recent distribution and accumulation of organic carbon on the continental margin west off Spitsbergen. Geochemistry Geophysics Geosystems 6.

Winsor, P., Björk, G., 2000. Polynya activity in the Arctic Ocean from 1958 to 1997. Journal of Geophysical Research 105, 8789-8803. 